\title{
PEMBAGIAN HAK WARIS KEPADA AHLI WARIS AB INTESTATO DAN TESTAMENTAIR MENURUT HUKUM PERDATA BARAT (BW)
}

Oleh :

Indah Sari, SH, M.Si ${ }^{1}$

(Indah.alrif@gmail.com)

\begin{abstract}
Abstrak:
Hukum Waris yang berlaku di Indonesia bersifat Pluralisme, artinyanya adalah bahwa hukum waris yang ada di Indonesia beranekaragam, ada Hukum Waris Perdata Barat (BW), Hukum Waris Islam dan Hukum Waris Adat. Hukum Waris Perdata Barat (BW) diperuntukkan bagi orang non muslim atau orang-orang yang tunduk pada ketentuan Hukum Waris Perdata Barat, Hukum Waris Islam diperuntukkan bagi orang Muslim dan Hukum Waris Adat diperuntukkan bagi masyarakat adat. Pada Hukum Waris Perdata Barat dikenal dua cara pembagian warisan untuk ahli waris yaitu: secara ab intestato (ahli waris mempunyai hubungan darah dan hubungan perkawinan dengan si pewaris) dan secara testamentair/surat wasiat (ahli waris ditentukan oleh si pewaris dalam surat wasiat. Kedua cara pembagian ini pada prinsipnya menekankan bahwa yang berhak mewaris adalah orang yang terdekat dengan si pewaris.
\end{abstract}

\footnotetext{
${ }^{1}$ Dosen tetap Fakultas Hukum Universitas Suryadarama dan aktif di Lembaga Konsultasi dan Bantuan Hukum (LKBH) Fakultas Hukum Universitas Suryadarama serta anggota dari Asosiasi Dosen Seluruh Indonesia (ADI) serta Asosiasi Auditor Hukum Indonesia (ASAHI)
} 


\section{PENDAHULUAN}

\section{PLURALISME HUKUM WARIS DI INDONESIA}

Sangat menarik untuk membahas Hukum Waris dalam kajian Ilmu Hukum, karena untuk membagi warisan tidaklah semudah yang dibayangkan, ada beberapa ketentuan yang harus diikuti bagi seseorang ketika ia ingin mewariskan warisannya kepada ahli warisnya. Indonesia belum mengenal adanya Unifikasi Hukum Waris (penyatuan hukum waris bagi seluruh warganegaranya. Hal ini disebabkan pertama, kultur budaya Indonesia yang beranekaragam, kedua, masalah waris masing-masing agama akan tunduk pada keyakinannya dalam pembagian warisan, ketiga, adanya kultur membagi warisan dengan cara kekeluargaan tanpa mengikuti peraturan perundang-undangan terutama ini berlaku pada masyarakat adat. Dengan tiga alasan diatas sangat sulit dilakukannya Unifikasi Hukum Waris di Indonesia.

Adapun hukum waris yang berlaku di Indonesia pada saat ini ada tiga bentuk hukum waris yaitu; pertama, Hukum Waris Perdata Barat, kedua, Hukum Waris Islam dan ketiga, Hukum Waris Adat. Sehingga di Indonesia dikenal dengan adanya Pluralisme Hukum Waris (Perberlakuaan berbagai macam bentuk hukum waris di Indonesia). Timbul pertanyaan, ketika terjadi pembagian warisan, hukum waris apa yang akan kita pakai? Apakah ketiga bentuk hukum waris tersebut akan kita gunakan? Jawabannya tidak!
Hukum Waris Perdata Barat (BW) hanya diperuntukkan bagi orangorang non muslim atau orang-orang yang tunduk kepada ketentuan hukum waris perdata barat, sedangkan hukum waris Islam diberlakukan untuk orang muslim sedangkan hukum waris adat diberlakukan untuk masyarakat adat. Apakah kita bisa memakai dua bentuk hukum waris dalam membagi warisan? Misalnya disamping memakai hukum Islam juga memakai hukum adat. Jawabannya tidak bisa, kita hanya bisa memilih salah satu hukum waris apa yang akan kita pakai dalam membagi warisan, tetapi untuk orang muslim mereka harus tunduk kepada ketentuan hukum waris Islam.

Bagaimana jika pewaris berbeda agama dengan si pewaris? Misalnya pewaris beragama Kristen sedangkan si ahli warisnya bergama Islam. Hukum waris apa yang akan dipakai? Jika ada kasus semacam ini di dalam hukum waris dikenal adanya asas Personalitas artinya dalam membagi warisan si pewaris dan si ahli waris berbeda agama maka hukum waris yang dipakai adalah mengaju kepada agama yang dianut oleh pewaris. Dalam kasus diatas tadi maka yang dipakai adalah hukum waris Perdata Barat (BW) karena si pewaris beragama non muslim.

Untuk lebih jelasnya mari kita lihat ciri-ciri dari masing-masing hukum waris tersebut: 


\section{CIRI-CIRI HUKUM WARIS PERDATA BARAT ${ }^{2}$}

a. Dasar Hukumnya Kitab UndangUndang Hukum Perdata (BW) terutama dalam Buku II BW (tentang harta kekayaan dan hutang)dan Buku III BW (tentang Wasiat)

b. Diperuntukkan bagi orang Non Muslim

c. Mewaris dari pihak bapak dan pihak ibu (Bilateral)

d. Tidak ada perbedaan bagian untuk anak laki-laki maupun untuk anak perempuan

e. Ahli waris adalah orang yang terdekat dengan si pewaris

f. Mewaris secara pribadi, tidak perkelompok

g. Terbukanya warisan ketika si pewaris meninggal dunia

h. Jika ada sengketa diselesaikan di Pengadilan Negeri.

\section{CIRI-CIRI HUKUM WARIS} ISLAM: ${ }^{3}$
a. Dasar hukumnya adalah Kompilasi Hukum Islam (KHI)
b. Diberlakukan untuk orang muslim
c. Mewaris dari dua pihak yaitu bapak dan ibu (Bilateral)

\footnotetext{
${ }^{2}$ Untuk memahami lebih dalam mengenai Hukum Waris Perdata Barat baca J Satrio, Hukum Waris, Alumni Bandung, 1992 dan baca juga Efendi Perangin, Hukum Waris, Rajawali Pers, Jakarta, 1997. Adapun dasar hukum berlakunya hukum waris perdata barat di Indonesia bisa dilihat dalam Kitab UndangUndang Hukum Perdata (BW) mulai dari pasal 830 KUH Perdata sampai 1130 KUH Perdata.

${ }^{3}$ Lihat lebih lanjut Kompilasi Hukum Islam Buku ke II dan Rachmadi Usman, Hukum Kewarisan Islam dalam Dimensi Kompilasi Hukum Islam, Mandar Maju, Bandung, 2009.
}

d. Bagian anak laki-laki 2x bagian anak perempuan

e. Ahli waris adalah orang yang terdekat dengan si pewaris

f. Mewaris secara Pribadi

g. Terbukanya warisan ketika pewaris meninggal dunia, kecuali hibah (pemberian orang tua kepada anaknya ketika orang tua masih hidup).

h. Jika terjadi sengketa diselesaikan di Pengadilan Agama (PA)

\section{CIRI-CIRI HUKUM WARIS}

\section{ADAT: ${ }^{4}$}

a. Dasar hukumnya adalah hukum adat setempat (Lokalistik) yang bergantung pada struktur kekerabatan yang dianut oleh masyarakat tersebut apakah Patrilineal (pewarisan pada anak laki-laki), Matrilineal ( pewarisan pada anak perempuan) ataukah Bilateral ( pewarisan pada anak laki-laki dan perempuan).

b. Diberlakukan bagi masyarakat adat dan tidak bersifat Nasional

c. Mewaris menurut sistem kekerabatan yang dianut apakah Patrilineal, Matrilineal ataukah Bilateral.

d. Bagian anak laki-laki dengan anak perempuan tidak sama

e. Ahli waris tidak selalu orang yang terdekat dengan si pewaris

f. Bisa mewaris secara pribadi ataupun perkelompok

g. Terbuka warisan bisa terjadi sebelum si pewaris meninggal dunia

\footnotetext{
${ }^{4}$ Untuk Memahami Hukum Waris Adat lihat lebih lanjut Hilman HadiKusuma, Hukum Waris Adat, PT. Citra Aditya Bakti, Bandung 2003 dan Soerjono Soekanto, Hukum Adat Indonesia, Rajawali Pers, Jakarta, 2010.
} 
h. Jika terjadi sengketa diselesaikan oleh Kepala Adat.

2. PEMBERLAKUAN HUKUM WARIS PERDATA BARAT (BW) DI INDONESIA

Di dalam tulisan ini penulis hanya mengambil salah satu bentuk hukum waris yang berlaku di Indonesia yaitu Hukum Waris Perdata Barat. Ada beberapa alasan mengapa penulis mengkaji lebih dalam Hukum Waris Perdata barat, pertama, hukum waris perdata barat adalah hukum waris yang tertua dalam bentuk tertulis yang diberlakukan di Indonesia karena berdasarkan kepada BW, di mana BW diberlakukan di Indonesia pada tahun 1848 dengan asas Konkordasi maksudnya adalah apa - apa peraturan yang diberlakukan di negeri Belanda juga di berlakukan didaerah jajahan Belanda termasuk Hindia Belanda (Indonesia), kedua, pembagian warisan secara hukum perdata barat lebih menekankan memberikan hak waris kepada keluarga yang sedarah atau yang terikat perkawinan, hal ini dianggap lebih adil kemudian adanya kesetaraan antara hak laki-laki dan perempuan dan yang ketiga, adanya cara pembagian warisan bisa dilakukan menurut cara $A b$ intestato bahwa ahli warisnya adalah orang yang mempunyai hubungan darah dengan si pewaris atau yang mempunyai hubungan perkawinan (ini secara tegas ditentukan oleh Undang-undang). Dan juga pembagian warisan bisa dilakukan secara testamentair (surat wasiat) bahwa ahli warisnya sudah ditentukan dalam surat wasiat oleh sipewaris. Dua cara ini mempunyai kelebihan dan kelemahan masing-masing bagi ahli waris. Ahli waris tinggal memilih ingin memakai cara $A b$ Intestato ataukah cara Testamentair.

Berdasarkan alasan yang ketiga inilah menulis ingin mengkaji lebih dalam lagi bagaimana cara pembagian warisan menurut cara $A b$ Intestato dan cara Testamentair yang diatur dalam Kitab Undang-Undang Hukum Perdata (BW). Dan sebelumnya penulis melihat bagaimana strutur hukum waris serta ketentuanketentuan apa yang harus diperhatikan sebelum membagi warisan menurut Hukum Perdata Barat (BW).

\section{PERMASALAHAN}

Adapun permasalahan yang diangkat dalam penulisan ini adalah

1. Apa saja ketentuan-ketentuan yang harus diperhatikan sebelum melakukan pembagian warisan menurut Hukum Waris Perdata Barat (BW)?

2. Bagaimanakah cara pembagian hak waris kepada ahli waris $A b$ Intestato dan Testamentair menurut ketentuan Hukum Waris Perdata Barat?

\section{PEMBAHASAN}

\section{PERATURAN YANG MENGATUR HUKUM WARIS PERDATA BARAT}

Hukum Waris Perdata Barat diatur dalam buku II KUH Perdata (BW). Jumlah pasal yang me ngatur hukum waris sebanyak 300 pasal yang dimulai dari pasal $830 \mathrm{KUH}$ Perdata sampai dengan $1130 \mathrm{KUH}$ Perdata yang di mulai dari Bab 12 sampai 
dengan $18 \mathrm{KUH}$ Perdata yang berisi tentang: ${ }^{5}$

a. Bab 12 tentang pewarisan karena kematian

b. Bab 13 tentang Surat wasiat

c. Bab 14 tentang pelaksanaan Surat Wasiat dan Pengurusan Harta Peninggalan

d. Bab 15 tentang Hak berfikir dan Hak Istimewa untuk merinci harta peninggalan

e. Bab 16 tentang hal menerima dan menolak warisan

f. Bab 17 tentang Pemisahan harta Peninggalan

g. Bab 18 tentang Harta Peninggalan yang tidak terurus.

Di dalam KUH Perdata (BW) tidak ditemukan pengertian hukum waris, tetapi yang ada hanya berbagai konsep-konsep tentang kewarisan, orang yang berhak dan tidak berhak menerima warisan dan lain-lain .

Vollmer berpendapat bahwa "Hukum waris adalah perpindahan dari sebuah harta kekayaan yang seutuhnya, jadi keseluruhan hak-hak dan kewajibankewajiban dari orang yang mewariskan kepada warisnya (Vollmer, 1989,373)". Pendapat ini hanya memfokuskan kepada pemindahan harta kekayaan dari pewaris kepada ahli warisnya. ${ }^{6}$

Pitlo berpendapat bahwa "Hukum Waris adalah kumpulan peraturan yang mengatur hukum kekayaan karena wafatnya seseorang yaitu mengenai pemindahan harta

${ }^{5}$ F.Satriyo Wicaksono, Hukum Waris, Cara Mudah dan Tepat Membagi Harta Warisan, Visi Media, Jakarta, 2011, hal 87.

${ }^{6}$ Salim HS, Pengantar Hukum Perdata Tertulis (BW) ,Sinar Grafika, Jakarta, 2005, hal 137. kekayaan yang ditinggalkan oleh si mati dan akibat dari pemindahan ini bagi orang-orang yang memperolehnya baik dalam hubungan antar mereka dengan phak ketiga (Pitlo, 1986:I)". Pendapat Pitlo ini agak luas, karena di dalam pemindahan kekayaan itu, tidak hanya hubungan antara ahli waris yang satu dengan ahli waris lainnnya, namun juga diatur tentang hubungan antara ahli waris dengan pihak ketiga . Hubungan dengan pihak ketiga ini berkaitan dengan masalah hutang piutang pada saat masih hidup ${ }^{7}$

Dari kedua definisi ini dapatlah disimpulkan bahwa hukum waris adalah keseluruhan dari kaidahkaidah hukum, baik yang tertulis maupun yang tidak tertulis, yang mengatur mengenai pemindahan harta kekayaan pewaris kepada ahli warisnya, bagian yang diterima serta hubungan antara ahli waris dengan pihak ketiga. Dari definisi ini dapat dikemukakan unsur-unsur yang terdapat dalam hukum waris:

a. Kaidah hukum

b. Pemindahan harta kekayaan pewaris

c. Ahli waris

d. Bagian yang diterima

e. Hubungan ahli waris dengan pihak ketiga

Menurut Hukum Perdata Barat bahwa Hukum Waris adalah hukum yang mengatur tentang peralihan harta kekayaan yang ditinggalkan seseorang yang meninggal serta akibatnya. Pada asasnya hanya hak-hak dan kewajiban-kewajiban dalam lapangan

${ }^{7}$ Ibid, hal 138 
hukum kekayaan/harta benda saja yang dapat di wariskan. ${ }^{8}$

Jadi melihat definisi dari pengertian hukum waris menurut Hukum Perdata Barat bahwa hukum waris terdiri dari tiga unsur yaitu:

a. Adanya Pewaris yaitu seseorang yang telah meninngal dunia dan meninggalkan warisan kepada ahli waris.

b. Warisan yaitu harta kekayaan atau hutang milik pewaris yang akhirnya menjadi hak ahli waris setelah pewaris meningggal dunia.

c. Ahli waris yaitu: orang yang berhak menerima warisan dari si pewaris menurut ketentuan perundang-undangan.

Diatas telah dijelaskan bahwa pewaris adalah seseorang yang telah meninggal dunia yang meninggalkan warisan kepada ahli waris. Bahwa sesuai dengan Pasal 830 KUH Perdata menyebutkan "Pewarisan hanya berlangsung karena kematian". Terbukalah warisan kepada ahli waris apabila si pewaris sudah meninggal dunia. Apakah warisan bisa diberikan kepada ahli waris jika si pewaris masih hidup? Jawabannya tegas "Tidak Bisa". Jadi, harta peninggalan baru terbuka jika si pewaris telah meninngal dunia menurut ketentuan Hukum Waris Perdata Barat.

Dalam hal ini ada ketentuan dalam Pasal 2 KUH Perdata, yaitu anak yang ada dalam kandungan seseorang perempuan dianggap sebagai telah dilahirkan bila kepentingan anak

${ }^{8}$ Efendi Perangin, Hukum Waris, Rajawali Pers, Jakarta, 1997 hal 3-4 menghendakinya. Mati sewaktu dilahirkan dianggap ia tidak pernah ada. ${ }^{9}$ Jelaslah seseorang anak yang lahir saat ayahnya telah meninggal dunia berhak mendapat warisan hal ini diatur dalam pasal $836 \mathrm{KUH}$ Perdata

2. CARA MENDAPATKAN WARISAN MENURUT HUKUM WARIS PERDATA BARAT (BW)

Dalam undang-undang terdapat dua cara untuk mendapatkan suatu warisan yaitu sebagai berikut: ${ }^{10}$

a. Secara Ab Intestato (ahli waris menurut Undang-Undang dalam Pasal $832 \mathrm{KUH}$ Perdata)

Menurut ketentuan undangundang, yang berhak menerima bagian warisan adalah para keluarga sedarah, baik sah maupun luar kawin dan suami istri yang hidup terlama. Keluarga sedarah yang menjadi ahli waris dibagi dalam empat golongan yang masing-masing merupakan ahli waris golongan pertama, kedua, ketiga dan golongan keempat. Mengenai golongan ahli waris ini akan dijelaskan lebih lanjut pada pembahasan cara pembagian hak ahli waris menurut cara $\mathrm{Ab}$ Intestato.

\footnotetext{
${ }^{9}$ Lihat lebih lanjut Pasal 2 Kitab Undang-Undang Hukum Perdata

${ }^{10}$ Lihat lebih lanjut Efendi Perangin, Hukum Waris, Rajawali Pers, Jakarta, hal 4 dan lihat juga Pasal 832 KUH Perda ta dan pasal 899 KUH Perdata.
} 
b. Secara testamentair (ahli waris karena ditunjuk dalam surat wasiat atau testament) hal ini di atur dalam pasal $899 \mathrm{KUH}$ Perdata

\section{SIFAT HUKUM WARIS PERDATA}

Adapun sifat hukum waris Perdata Barat (BW) adalah:

a. Bahwa Hukum Waris Perdata Barat bersifat perseorangan, bukan kelompok ahli waris. Maksudnya di sini adalah bahwa ahli waris adalah perorangan (perindividu) dan tidak dikenal adanya ahli waris yang berkelompok.

b. Bersifat Bilateral

Bahwa ahli waris mewaris dari dua pihak yaitu ahli waris berhak mendapatkan warisan dari pihak bapak maupun pihak ibu.

c. Bersifat sistem perderajatan

Bahwa ahli waris yang derajatnya lebih dekat dengan sipewaris menutup ahli waris yang lebih jauh derajatnya. Maksudnya adalah, seperti yang sudah dijelaskan diatas bahwa di dalam Undang-Undang terdapat dua cara untuk mendapatkan warisan, salah satunya adalah secara $A b$ intestato yang dikenal dengan adanya empat golongan ahli waris bahwa :

- Selagi masih ada golongan I, maka tertutuplah kemungkinan golongan II, II, dan IV untuk menerima warisan dari ahli waris.

- Jika golongan I tidak ada maka golongan II lah yang berhak menerima warisan dari pewaris dan tertutuplah hak waris untuk golongan III dan IV.

- Jika golongan II tidak ada maka yang berhak menerima warisan adalah golongan III dan tertutuplah hak waris bagi golongan IV.

- Jika ahli waris golongan III tidak ada maka yang berhak menerima warisan adalah ahli waris golongan IV.

Jika semua ahli waris tidak ada maka seluruh warisan akan di serahkan kepada negara.

\section{TIDAK PATUT MENJADI AHLI WARIS}

Di dalam Hukum Waris Perdata Barat (BW) Pasal 838 ada beberapa orang yang tidak patut menjadi ahli waris (Onwaardig): ${ }^{11}$ yaitu:

a. Orang yang telah dihukum karena membunuh atau mencoba membunuh pewaris. Dalam hal ini sudah ada keputusan hakim, akan tetapi jika sebelum keputusan hakim itu dijatuhkan, si pembunuh sudah meninggal dunia, maka ahli warisnya dapat menggantikan kedudukannya. Pengampunan (grasi) tidak

${ }^{11}$ Pasal 838 Kitab Undang-Undang Hukum Perdata 
menghapus keadaan "tidak patut mewaris"

b. Orang yang dengan keputusan hakim pernah dipersalahkan memfitnah si pewaris, berupa fitnah dengan ancaman hukuman lima tahun atau lebih berat. Dalam hal ini harus ada keputusan hakim yang menyatakan bahwa yang bersangkutan bersalah karena memfitnah.

c. Orang yang dengan kekerasan atau perbuatan telah mencegah si pewaris untuk membuat atau mencabut surat wasiatnya.

d. Orang yang telah menggelapkan, merusak atau memalsukan surat wasiat si pewaris.

Kejadian yang disebut dalam poin c dan d jarang terjadi, sebab surat wasiat dibuat di depan notaris.

Pasal 839 menyatakan: ${ }^{12}$

"Tiap-tiap waris yang tidak patut menjadi ahli waris wajib mengembalikan segala hasil pendapatan yang telah dinikmatinya semenjak warisan terbuka"

\section{MEWARIS LANGSUNG ATAU MENGGANTI}

Dalam mewaris menurut undangundang dibedakan adanya: ${ }^{13}$

a. Mewaris langsung

b. Mewaris mengganti

Ad1. Mewaris langsung ialah orang itu mewaris dalam kedudukannya sebagai ahli waris langsung karena dirinya sendiri (uit eigen hoofed)

Ad2. Mewaris tidak langsung /mewaris karena penggantian ( $b i j$ plaatsvervulling ) ialah mewaris untuk orang yang sudah meninggal terlebih dahulu daripada si pewaris. Ia menggantikan ahli waris yang telah meninggal lebih dahulu dari si pewaris.

Contoh 1:

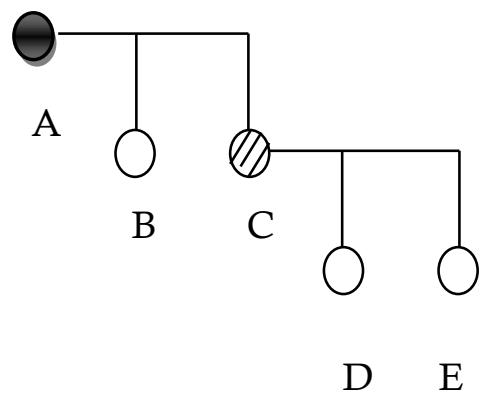
$A$ : si pewaris yang meninggal
B, C : Anak dari A
D dan $\mathrm{E}$ : Anak dari $\mathrm{C}$
$\mathrm{C}$ meninggal lebih dahulu dari A
$B$ adalah ahli waris langsung
$\mathrm{D}$ dan $\mathrm{E}$ ahli waris tidak langsung (Pengganti C)

Pasal 840 KUH Perdata mengatur bahwa apabila anak-anak dari seorang yang telah dinyatakan tidak patut menjadi waris, atas dirinya sendiri mempunyai panggilan untuk menjadi waris, maka tidaklah karena kesalahan orang tua tadi dikecualikan dari pewarisan. ${ }^{14}$

\footnotetext{
${ }^{12}$ Pasal 839 Kitab Undang-Undag Hukum Perdata

${ }^{13}$ Efendi Perangain, Op. Cit, hal 10-11.
}

\footnotetext{
${ }^{14}$ Lihat lebih lanjut pasal 840 KUH Perdata
} 
Contoh 2

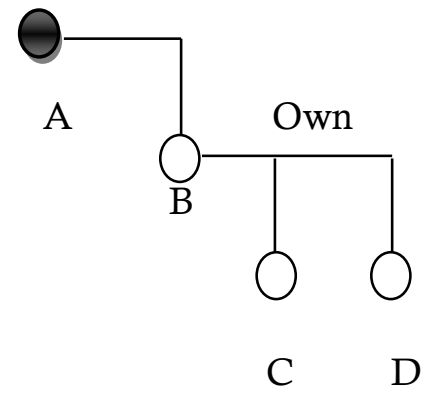

A meninggal

B Onwaardig terhadap A. C dan D anak B atau cucu A. Dalam hal ini tidak ada ahli waris lainnya maka $\mathrm{C}$ dan $\mathrm{D}$ mewaris atas dirinya (uit eigen hoofde) terhadap harta peninggalan $\mathrm{A}$

\section{Contoh 3}

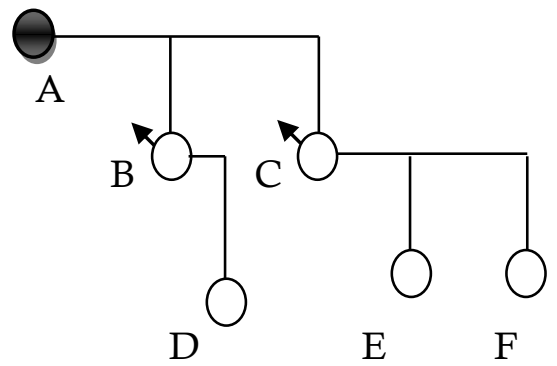

A : Pewaris meninggal dunia

B dan C: Anak-anak dari A dan mereka menolak warisan

D: Anak sah B

E,F: anak sah C

Dalam hal ini D,E dan F mewaris "uit eigen hoofde"

\section{MENOLAK WARISAN}

Adapun dasar hukum yang mengatur penolakkan warisan diatur dalam Pasal 1057, 1058,
1059 dan Pasal 1060 KUH

Perdata. Dalam pasal - pasal ini pada dasarnya dijelaskan bahwa si ahli waris melepas pertanggungjawabannya sebagai ahli waris dan menyatakan tidak menerima pembagian harta peninggalan. ${ }^{15}$ Dalam Pasal 1058 ditegaskan lagi akibat penolakkan tersebut seseorang akan kehilangan haknya untuk mewaris, sehingga orang itu dianggap tidak pernah menjadi ahli waris sebuah pertanyaan, bagaimanakah caranya penolakan warisan tersebut?

Seorang ahli waris dapat menolak warisan yang terbuka baginya. Terjadinya penolakan dihitung sejak hari si pewaris meninggal dunia, jadi berlaku surut (Pasal 1047) dan bagian Legitieme Portienya juga akan hilang. Ahli waris yang menolak warisan berarti melepaskan pertanggung jawabannya sebagai ahli waris dan tidak menerima pembagian harta peninggalan. ${ }^{16}$

Penolakkan haruslah dinyatakan dengan tegas dan harus dengan memberikan pernyataan di depan panitera pengadilan negeri di wilayah hukum warisan tersebut terbuka (Pasal 1057 KUH Perdata). Dalam hal ini, penolak warisan harus datang menghadap ke Panitera Pengadilan Negeri setempat, lalu menyatakan keinginannya dan panitera

\footnotetext{
${ }^{15}$ Untuk memahami lebih lanjut bagaimana proses penolakkan warisan dan akibat hukumnya dalam Hukum Waris Perdata Barat bisa dikaji dalam Pasal 1057, 1058,1059 dan 1060 KUH Perdata

${ }^{16}$ Pasal 1047 KUH Perdata dan lihat juga Efendi Perangin, Op.Cit, hal 171.
} 
membuat akta penolakkan. Apabila si penolak warisan tidak datang sendiri, ia boleh menguasakan penolakkan itu kepada orang lain. Akan tetapi surat kuasa itu haruslah notariil.

Hak untuk menolak baru timbul setelah warisan terbuka dan tidak dapat gugur karena daluwarsa (Pasal 1062 KUH Perdata). Sedangkan akibat dari penolakkan warisan diatur dalam Pasal1058,1059 dan 1060.

Pasal 1058:

"Si pewaris yang menolak warisannya, dianggap tidak pernah menjadi waris" jatuh kepada mereka yang sedianya berhak atas bagian itu, seandainya si yang menolak itu tidak hidup pada waktu meninggalnya orang yang mewariskan"

Pasal 1059

"Bagian warisan seorang yang menolak jatuh kepada mereka yang sedianya berhak atas bagian itu , seandainya si yang menolak itu tidak hidup pada waktu meninggalnya orang yang mewariskan."

Contoh:

A meninggal, meninggalakan istrinya $B$ dan dua orang anak C dan D. C menolak warisan

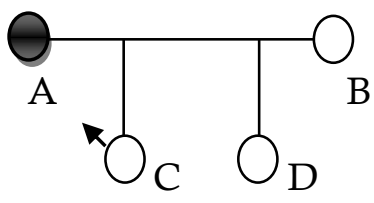

Menurut Pasal 1058, C dianggap tidak ada dan juga menurut Pasal 1059 bagian $C$ yang menolak warisan tersebut jatuh kepada B dan $\mathrm{D}$ dengan bagian sama banyak.

Pasal 1060 :

"Siapa yang telah menolak suatu warisan, tidak sekali-kali dapat diwakili dengan cara pergantian, jika satu-satunya waris di dalam derajatnya ataupun jika kesemuanya waris menolak, maka sekalian anak-anak tampil ke muka atas dasar kedudukan mereka sendiri dan mewaris untuk bagian yang sama."

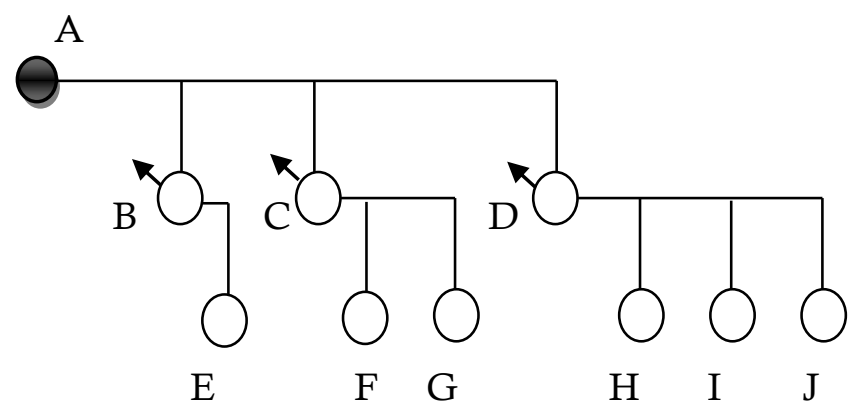

A: Pewaris meninggal dunia B,C,D : anak-anak sah A dan semuanya menolak warisan dari $\mathrm{A}$. E: Anak sah B $F$ dan $G$ : anak sah $C$ H,I,J : anak-anak sah D

Berdasarkan Pasal 1060 KUH Perdata bahwa yang mewaris adalah E,F,G,H,I dan J (uit eigen hoofde)

Didalam sistem penolakkan warisan ini juga ditegaskan bahwa sekali ahli waris menolak dia tetap dinayatakan menolak dan penolakan tidak dapat dibatalkan, 
kecuali ada penipuan atau paksaan yang menyebabkan seseorang menolak (Pasal 1065 KUH Perdata).

Ahli waris yang menolak warisan dianggap tidak pernah menjadi ahli waris. Bagian warisan dari orang yang menolak warisan tersebut jatuh ke tangan orang yang sedianya berhak atas bagian itu, andaikata orang yang menolak itu tidak ada pada waktu pewaris meninggal, misalnya seorang cucu yang tampil sendiri karena orang tuanya menolak menerima warisan.

Orang yang telah menolak warisan sekali-kali tidak dapat diwakili dengan penggantian ahli waris apabila orang tersebut merupakan satu-satunya ahli waris dalam derajatnya, atau apabila semua ahli waris menolak warisannya, anakanak mereka menjadi ahli waris karena diri mereka sendiri dan mewarisi bagian yang sama.

\section{PEMBAGIAN HAK WARIS AHLI WARIS SECARA $A B$ INTESTATO DAN TESTAMENTAIR}

\section{A. PEMBAGIAN SECARA $A B$ INTESTATO}

Menurut ketentuan ini yang berhak menerima bagian warisan (ahli waris) adalah para keluarga sedarah, baik sah maupun luar kawin dan suami atau istri yang hidup terlama.
Keluarga sedarah yang menjadi ahli waris ini dibagi menjadi empat golongan yang masing-masing merupakan ahli waris golongan pertama, kedua, ketiga dan keempat. Mengenai golongan ahli waris ini akan penulis jelaskan sebagai berikut beserta berapa besar bagian masing-masing ahli waris menerima warisan dari pewaris:

Dalam KUH Perdata terdapat empat golongan ahli waris

\section{Golongan I}

Suami /istri yang hidup terlama serta anak-anak dan keturunannya (cucu-cucunya)

Bagan

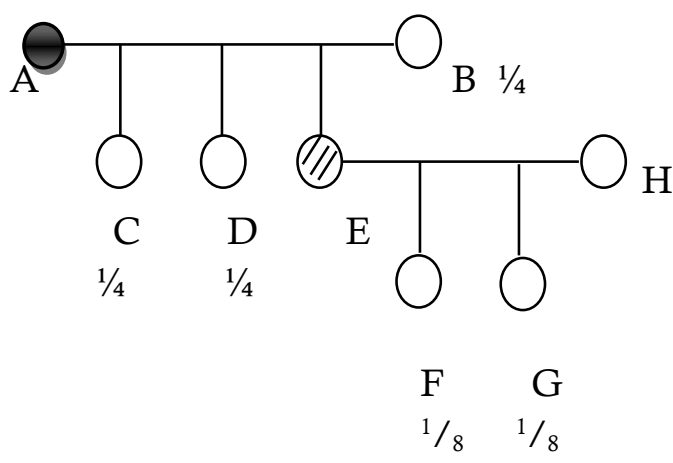

Keterangan

A: pewaris meninggal dunia (suami)

$\mathrm{B}$ : Istri sah A

C,D,E: anak-anak sah dari A dan B

H: Menantu dan B

F dan G: anak anak $\mathrm{E}$ dan $\mathrm{H}$ (cucu-cucu A dan B)

$\mathrm{E}$ : meninggal dunia lebih dahulu dari A 


\section{Golongan II}

Orang tua (ayah dan ibu), saudara - saudara serta keturunan saudara-saudara

Bagan

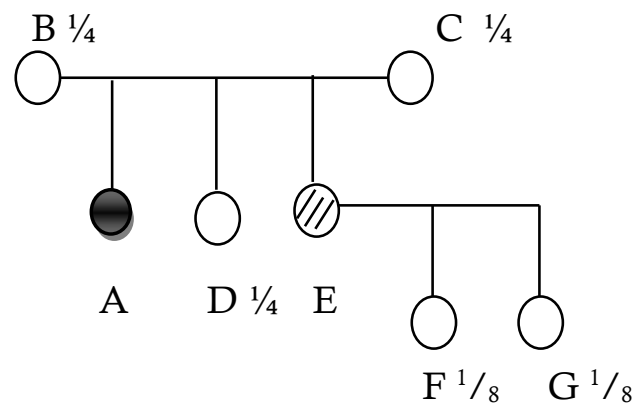

Keterangan

A: Orang yang meninggal dunia

B: Ayah kandung dari A

C: Ibu kandung dari A

D dan E: Saudara-saudara kandung dari A

F dan G: Keponakan dari A atau anak kandung dari $\mathrm{E}$ $\mathrm{E}$ : meninggal lebih dahulu dari A

\section{Golongan III}

Keluarga dalam garis lurus keatas sesudah bapak dan ibu

Bagan

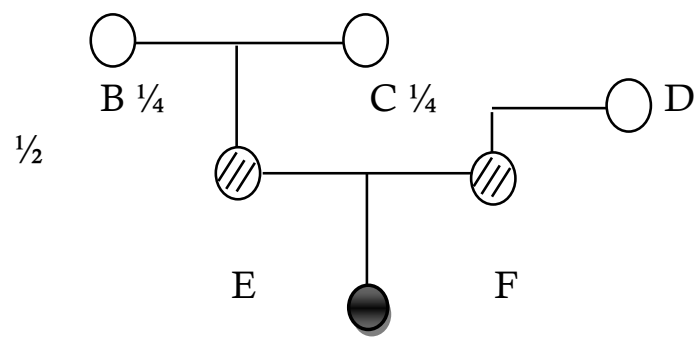

A
Keterangan

A: Pewaris meninggal dunia B: kakek dari A dari pihak bapak

C: Nenek dari A dari pihak bapak

D: Nenek dari A dari pihak ibu

E: Bapak meninggal lebih dahulu dari A

F: ibu meninggal lebih dahulu dari A

\section{Golongan IV}

Keluarga garis lurus kesamping dari pihak ayah sampai derajat keenam dan keluarga garis lurus kesamping dari pihak ibu sampai derajat keenam.

Bagan

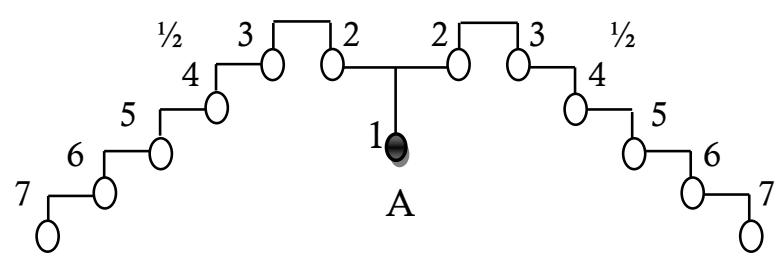

Keterangan:

A: Pewaris meninggal dunia, sebelah kiri garis lurus kesamping dari pihak ayah sampai derajat ke enam dan sebelah kanan garis lurus kesamping dari pihak ibu sampai derajat ke enam, masing-masing mendapatkan 
bagian dari garis ayah $1 / 2$ dan dari garis $i b u 1 / 2$

Ada beberapa hal yang perlu diperhatikan dalam membagi warisan dengan cara $A b$

Intestato:

1. Jika tidak ada keempat golongan tersebut, maka harta peninggalan jatuh kepada negara.

2. Golongan yang terdahulu menutup golongan yang kemudian, jadi jika ada ahli waris golongan I, maka ahli waris golongan II,III dan IV tidak menjadi ahli waris

3. Jika golongan I tidak ada, golongan II lah yang mewaris. Golongan III dan IV tidak mewaris .

4. Dalam golongan I termasuk anak-anak sah maupun luar kawin yang diakui sah dengan tidak membedabedakan laki-laki ataupun perempuan dan perbedaan umur.

5. Apabila si meninggal tidak meninggalkan keturunan maupun suami atau istri, atau juga saudara-saudara, maka warisan harus dibagi dalam dua bagian yang sama pembagian itu berupa satu bagian untuk sekalian keluarga sedarah dalam garis bapak keatas dan satu bagian lagi untuk sekalian keluarga yang sama dalam garis ibu.
6. Dengan demikian apabila ahli waris golongn I dan golongan II tidak ada, maka yang mewaris adalah golongan III, dan jika ahli waris golongan III tidak ada maka yang mewaris adalah golongan IV.

7. Bagian untuk ahli waris golongan I dibagi sama rata/sama besar untuk tiaptiap ahli waris begitu juga untuk ahli waris golongan II.

8. Untuk golongan III dan IV dalam hal ini harta warisan dibagi sama besar. Setengah untuk keluarga sedarah garis bapak dan setengah lagi untuk keluarga sedarah garis ibu.

Untuk lebih jelas lagi marilah kita bahas kasus di bawah ini:

\section{Kasus}

A: pewaris/suami meningagal dunia, meninggalkan harta warisan Rp. 600 juta

B: Istri sah A

C, D, E: anak-anak sah dari A dan B. Dimana C meninggal lebih dahulu dari A

E,F : Ayah Ibu kandung A

$\mathrm{H}$ : Istri C

I: Istri E

$\mathrm{J}, \mathrm{K}$ : Anak-anak sah dari C dan $\mathrm{H}$

L,M: Anak-anak sah dari D dan I

$\mathrm{N}, \mathrm{O}$ : Saudara - saudara kandung A 
Pertanyaan:

1. Buatlah bagan dari kasus diatas

2. Siapakah yang berhak menjadi ahli waris A

3. Siapa ahli waris langsung dan ahli waris pengganti?

4. Berapa bagian masingmasing ahli waris menerima warisan dari A?

Jawab:

1. Bagan dari kasus:

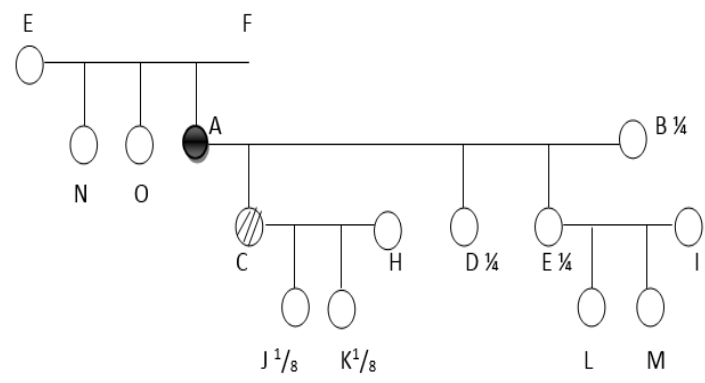

2. Yang berhak menjadi ahli waris adalah: B (istri), D dan $\mathrm{E}$ (anak-anak sah $\mathrm{A}$ ) dan dan J dan K (cucu-cucu A)

Kenapa mereka yang berhak menjadi ahli waris? Karena mereka termasuk Golongan I, selagi ada golongan I maka tertutuplah ahli waris golongan yang lainnya

3.Ahli waris langsung adalah B, D dan E mereka mewaris langsung dari A, sedangkan ahli waris tidak langsung adalah $\mathrm{J}$ dan $\mathrm{K}$ mereka adalah ahli waris pengganti yang menggantikan posisi $\mathrm{C}$ yang telah meninggal lebih dahulu dari A.
4. Bagian yang diterima ahli waris adalalah:

B Istri: $1 / 4$ x Rp 600 juta

$$
=\text { Rp. } 150 \text { juta }
$$

D anak sah A: 1/4xRp 600 juta $=$ Rp. 150 juta

E anak sak A: 1/4x Rp 600 juta $=$ Rp. 150 juta

J cucu A: 1/8x Rp 600 juta

$$
=\text { Rp. } 75 \text { juta }
$$

K cucu A: 1/8x Rp 600 juta

$$
=\text { Rp. } 75 \text { juta }
$$

Total warisan yang ditinggalkan Rp. 600 Juta

\section{B. PEMBAGIAN SECARA TESTAMENTAIR}

Pembagian hak waris kepada ahli waris secara testamentair adalah pembagaian dengan cara Surat Wasiat, dimana sebelum meninggal dunia si pewaris membuat surat wasiat dan menetapkan di dalam surat wasiatnya siapa-siapa yang dia inginkan menjadi ahli waris. Surat wasiat dalam hukum waris perdata barat haruslah dibuat tertulis oleh si pewaris. Kenapa harus tertulis? Ini untuk menjamin sebuah kepastian hukum dalam pembgian warisan menurut cara hukum perdata barat. Kemudian juga untuk alat bukti yang pasti dan jelas jika nantinya ada pihak-pihak yang tidak merasa puas akan pembagian warisan tersebut dan bisa juga digunakan sebagai alat bukti di pengadilan. 
Dalam menunjuk ahli waris di dalam surat wasiatnya si pewaris harus tetap mengaju kepada KUH Perdata dimana ada ketentuan bahwa sebelum penetapkan ahli waris dalam surat wasiatnya si pewaris harus memberikan bagian yang mutlak (Ligitieme Portie) kepada legitimaris ( ahli waris yang mempunyai hubungan darah dengan pewaris dalam garis vertikal).

Marilah kita kaji lebih dalam bagaimana pembagian warisan secara testamentair ini. Tapi kita akan memulainya dengan apa itu wasiat? Pasal 857 KUH Perdata memberikan definisi wasiat sebagai berikut: "Surat wasiat atau testament adalah suatu akta yang berisi pernyataan seseorang tentang apa yang akan terjadi setelah ia meninggal, dan olehnya dapat ditarik kembali". Dengan demikian, maka suatu testament adalah suatu akta, suatu keterangan yang dibuat sebagai pembuktian dengan campur tangan pejabat resmi. ${ }^{17}$

Pasal 897KUH Perdata menyatakan:

"Pembuat testament harus mempunyai budi akalnya, artinya tidak boleh membuat testament ialah orang sakit

${ }^{17}$ Mengenai definisi testament lihat lebih lanjut pasal $857 \mathrm{KUH}$ Perdata dan siapa-siapa saja yang tidak boleh membuat testament lihat lebih lanjut pasal 895 dan pasal pasl $897 \mathrm{KUH}$ Perdata. ingatan dan orang yang sakitnya begitu berat, sehingga ia tidak dapat berfikir secara teratur"

Pasal 897 menyatakan:

" Orang yang belum dewasa dan belum berusia 18 tahun tidak dapat membuat testament"

Adapun jenis-jenis Surat Wasiat adalah:

Menurut isinya, maka ada dua jenis surat wasiat: ${ }^{18}$

1. Wasiat yang berisi atau wasiat pengangkatan waris.

Wasiat pengangkatan waris adalah wasiat dengan mana orang yang mewasiatkan memberikan kepada seseorang atau lebih dari seseorang, seluruh, atau sebagian (setengah, sepertiga) dari harta kekayaannya kalau ia meninggal duni . Orangorang yang mendapatkan harta kekayaan menurut ketentuuan ini ada adalah waris.

2. Wasiat yang berisi hibah (Hibah wasiat)/Legaat

Hibah wasiat adalah suatu penetapan yang khusus di dalam suatu testamen, dengan mana yang mewasiatkan memberikan

${ }^{18}$ Ali Afandi, Hukum Waris, Hukum Keluarga dan Hukum Pembuktian Menurut BW, BIna Aksara, Jakarta, 1983, hal 16-17 
kepada seseorang atau beberapa orang berupa:
a. Beberapa barang tertentu
b. Barang-barang dari satu jenis tertentu
c. Hak pakai hasil dari seluruh atau sebagian, dari harta peninggalannya.

Orang - orang yang mendapatkan harta kekayaan menurut pasal ini disebut waris. Hibah wasiat diberikan ketika si pewaris sudah meninggal dunia, dan ini berbeda dengan hibah yang dapat diberikan sebelum penghibah meninggal dunia.

Menurut bentunya maka surat wasiat dibagi menjadi tiga macam: ${ }^{19}$

\section{Openbaar testament}

Bahwa testament dibuat oleh seorang notaris. Orang yang akan meninggalkan warisan menghadap kepada notaris dan menyatakan kehendaknya kepada notaris tersebut dengan dihadiri oleh dua orang saksi.

\section{Olographis testament}

Suatu testament yang ditulis sendiri oleh orang yang akan meninggalkan warisan dan diserahkan kepada notaris untuk disimpan dengan dihadiri oleh dua orang saksi.

3. Testament tertutup (rahasia)

Suatu testament yang dibuat sendiri oleh orang yang akan meninggalkan warisan, tetapi tidak diharuskan menulis dengan tangannya sendiri, namun harus selalu tertutup dan disegel. Dalam peyerahannya kepada notaris harus selalu tertutup dan disegel.

Seperti yang telah dijelaskan diatas bahwa dalam pembagian warisan menurut cara testament ada istilah Legitieme Portie yaitu bagian mutlak untuk ahli waris legitimaris. Bagian mutlak adalah suatu bagian dari harta peninggalan yang harus diberikan kepada para ahli waris yang berada dalam garis lurus (vertikal) menurut undang-undang. Si pewaris tidak diperbolehkan menetapkan sesuatu, baik selaku pemberiaan antara yang masih hidup maupun selaku wasiat (Pasal 913 KUH Per). Dengan demikian, legitimaris haruslah ahli waris menurut undang-undang dalam garis lurus keatas atau kebawah, misalkan : nenek, kakek, ayah, ibu, anak-anak dan cucu-cucu. Selain itu ada pula ahli waris menurut undang-undang yang bukan legitimaris, misalnya suami atau istri atau saudarasaudara.

${ }^{19}$ Ibid, hal 17 
Ada beberapa hal yang perlu diperhatikan yang berkaitan dengan legitimaris: ${ }^{20}$

1. Orang yang bukan legitimaris dapat dikesampingkan dengan surat wasiat

2. Bagian mutlak harus selalu dituntut. Apabila tidak dituntut maka tidak memperoleh legitieme portie. Jadi kalau ada tiga legitimaris dan yang menuntut hanya satu maka yang menuntut itu saja yang dapat. Yang dua yang tidak menuntut tersebut maka tidak dapat.

3. Seorang legitimaris berhak menuntut/melepaskan "legitieme portienya" tanpa bersama-sama dengan ahli waris legitimaris lainnya.

4. Penuntutan atas bagian mutlak baru dapat dilakukan terhadap hibah/hibah wasiat yang mengakibatkan

berkurangnya bagian mutlak dalam suatu harta peninggalan setelah warisan terbuka (Pasal 920 KUH Per)

5. Penuntutan itu dapat dilakukan terhadap segala macam pemberian yang telah dilakukan oleh si pewaris, baik beruap erfstelling (pengangkatan sebagai ahli waris), hibah wasiat atau terhadap segala pemberian yang dilakukan oleh si pewaris

${ }^{20}$ Efendi Perangin, Op.Cit, hal 54.

sewaktu si pewaris masih hidup (hibah)

6. Apabila si pewaris mengangkat seorang ahli waris dengan wasiat untuk seluruh harta peninggalannnya, maka bagian ahli waris yang tidak menunutut menjadi bagian ahli waris menurut wasiat itu.

Mengenai besarnya legitieme portie diatur dalam Pasal 914-916 KUH Perdata yang sebagai mana diuaraikan dibawah ini. ${ }^{21}$

\section{Pasal 914 (Legitieme Portie} anak-anak sah)

"Dalam garis lurus ke bawah, apabila si yang mewariskan hanya meninggalkan anak sah satu-satunya saja, maka bagian mutlak itu $1 / 2$ dari harta peninggalan, yang oleh si anak itu dalam pewarisan sedianya harus diperbolehkan......"

"Apabila dua orang anak yang ditinggalkannya, maka bagian mutlak itu adalah masingmasing 2/3 dari apa yang sedianya harus diwaris oleh mereka masing-masing dalam pewarisan"

Jadi kesimpulannya:

a. Jika hanya ada satu orang anak sah, maka Legitieme portienya (LP) $=1 / 2 \times$ bagian menurut undangundang.

b. JIka ada dua orang anak sah, maka LP-nya $=2 / 3 \mathrm{x}$ bagian menurut undang-undang

${ }^{21}$ Lihat Pasal 914, 915 dan 916 KUH Perdata. 
c. Jika ada tiga orang atau lebih anak sah, maka LP-nya $=3 / 4$ bagian menurut undang-undang.

Pasal 915 KUH Perdata menyatakan:

"Dalam garis lurus keatas bagian yang mutlak itu adalah selamanya setengah dari apa yang menurut undang-undang menjadi bagian tiap -tiap mereka dalam garis itu dalam pewarisan karena kematian "

Jadi besarnya Legitieme Portie bagi legitimaris garis vertikal keatas adalah selamanya $=1 / 2$ $\mathrm{x}$ bagian masing-masing menurut undang-unadang

Jadi kita dapat menyimpulkan bahwa dalam pembagian warisam menurut cara testament ini dikenal adanya ahli waris yang ditunjuk oleh si pewaris dalam surat wasiatnya kemudian adanya ahli waris legitimaris $y$ angmempunyai hak mutlak (legitieme portie) yang mana ketentuannya telah diatur dalam undang-undang serta berapa besar bagian dari tiaptiap legitimaris tersebut. Kemudian ada juga persyaratan lainnya yang harus diperhatikan dalam membuat surat wasiat oleh si pewaris yaitu bahwa yang boleh membuat surat wasiat adalah orang yang telah berumur 18 tahun, telah dewasa (sudah menikah, walaupun belum berusia 18 tahun) dan berakal sehat. Dalam membuat surat wasiat sebaiknya menghadirkan saksi dalam pembuatan surat wasiat tersebut. Untuk apa dihadirkan saksi? Hal ini berguna untuk pembuktian di pengadilan jika ada sengketa dikemudian hari. Saksi haruslah sudah dewas , penduduk Indonesia dan paham/mengerti bahasa yang digunakan dalam testament.

Apakah surat wasiat dapat dicabut? Jawabannya dapat tetapi harus tunduk kepada aturan-aturan tertentu bahwa pencabutan surat wasiat itu atas kehendak si pewasiat dan harus dinyatakan dengan tegas dalam sebuah akta atau dalam pencabutannya dapat dinyatakan secara diam-diam dengan membuat testament baru yang bertentangan dengan testament lama. Atau juga bisa testament batal jika pelaksanaannya tidak mungkin.

Inilah segelintir tentang ketentuan-ketentuan apa yang harus diperhatikan ketika membagi warisan menggunakan cara testament (surat wasiat). Untuk lebih jelas lagi penulis akan paparkan sebuah kasus yang berkaitan pembagian warisan menurut cara testament (Surat wasiat).

Kasus

A : Suami meninggal dunia/pewaris

B: Istri sah A

C, D : anak-anak sah A 
G, H anak-anak angkat A tanpa surat penetapan dari pengadilan

E, F : Saudara- saudara kandung A

Dalam hal ini A meninggalkan harta warisan Rp 900 Juta.

\section{Pertanyaan}

1. Buatlah bagan dari gambar diatas

2. Tunjukkan mana ahli waris legitimaris dan mana ahli waris yang ditunjuk oleh pewaris dalam surat wasiat!

3. Berapa masing-masing ahli waris menerima warisan dari A?

\section{Jawab}

1. Bagan

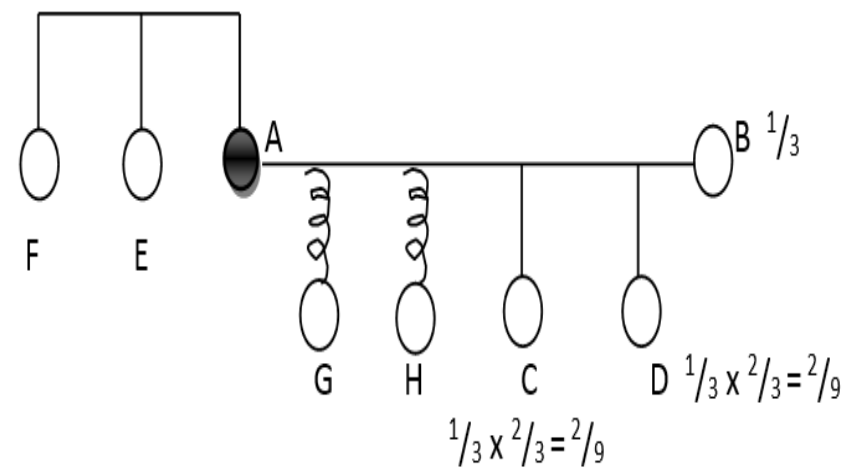

\section{PENUTUP}

\section{A. KESIMPULAN}

Bahwa pada prinsipnya Hukum Waris Perdata Barat (BW)
2. Ahli waris legitimaris adalah $\mathrm{C}$ dan D. Sedangkan B, G, H, F ,E bukan merupakan ahli waris legitimaris karena tidak mempunyai hubungan darah secara vertikal dengan $\mathrm{A}$.

Ahli waris yang ditunjuk oleh $\mathrm{A}$ dalam surat wasiatnya (ahli waris wasiat) adalah $\mathrm{E}$ dan $\mathrm{F}$

3. Bagian masing-masing ahli waris menerima warisan adalah: $\mathrm{C}=1 / 3 \times 2 / 3 \times$ Rp.900 Juta

$$
\begin{array}{rl}
= & \text { Rp. } 200.000 \\
\mathrm{D}=1 / 3 \times 2 / 3 \times R p & 900 \mathrm{Juta} \\
& =\text { Rp. } 200.000
\end{array}
$$

Sisa warisan A yang Rp 600 Juta lagi diserahkan kepada $\mathrm{G}$ dan $\mathrm{H}$ sebagai ahli waris wasiat (ahli waris yang ditunjuk oleh A dalam surat wasiatnya) dan dibagi dua antara $\mathrm{G}$ dan $\mathrm{H}$. Jadi:

$\mathrm{G}=\mathrm{Rp} .600 .000: 2=\mathrm{Rp} .300 .000$

$\mathrm{H}=$ Rp.600.000:2 = Rp.300.000

Total

= Rp. 900.000

menekankan bahwa yang paling berhak mewaris adalah orang yang paling terdekat dengan si pewaris terutama orang-orang yang mempunyai hubungan darah dan hubungan perkawinan dengan si pewaris. Adapun jika pembagian warisan dalam Hukum Warsis Perdata Barat bisa dilakukan dengan cara $A b$ Intestato (ahli waris yang berhak adalah ahli waris yang mempunyai hubungan darah dan hubungan perkawinan dengan si pewaris) dan juga melalui surat wasiat/testamentair (ahli waris ditunjuk dalam surat wasiat tapi 
tidak boleh mengabaikan hak legitimaris (Legitieme Portie). Ahli waris legitimaris harus diberikan haknya terlebih dahulu barulah kemudian ahli waris yang ditunjuk dalam surat wasiat.

\section{B. SARAN}

Bagi orang-orang yang tunduk kepada hukum Perdata sebaiknya sebelum membagi warisan kepada ahli warisnya harus memahami terlebih dahulu ketentuan dan syarat-syarat bagaimana membagi warisan menurut Hukum Perdata Barat terutama harus didasarkan kepada Kitab Undang-Undang Hukum Perdata sehingga nantinya warisan akan jatuh kepada ahli waris yang berhak disamping itu untuk menghindari sengketa antar ahli waris dikemudian hari.

\section{DAFTAR PUSTAKA}

Afandi, Ali, Hukum Waris Hukum keluarga Hukum Pembuktian Menurut Kitab UndangUndang Hukum Perdata (BW), Bina Akasara, Jakarta, 1983.

Hadikusuma, Hilman, Hukum Waris Adat, Citra Aditya Bakti, Bandung, 2003.

HS, Salim, Pengantar Hukum Perdata Tertulis (BW), Sinar Grafika, 2005, Jakarta.

Perangin, Efendi, Hukum Waris, Rajawali Pers, 1997, Jakarta

Satrio, J, Hukum Waris, Alumni, 1992, Bandung

Soekanto Soerjono, Hukum Adat Indonesia, Rajawali Pers, 2010, Jakarta.
Usman Rachmadi, Hukum Kewarisan Islam Dalam Dimensi Kompilasi Hukum Islam, Mandar Maju, Bandung, 2009

Wicaksono, F. Satriyo, Hukum Waris Cara Mudah dan Tepat Membagi Harta Warisan, Visi Media, 2011, Jakata

KItab Undang-Undang Hukum Perdata (BW)

Kompilasi Hukum Islam (KHI) 